\title{
¿QUÉ MÁS PODEMOS AGREGAR SOBRE NICANOR PARRA A SUS 100 AÑOS?
}

\section{THOMAS HARRIS*}

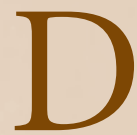
AR UN “TESTIMONIO” PERSONAL sobre Nicanor Parra a sus cien años de vida es complejo o más bien complicado, por lo inesperado y anómalo en la lírica chilena de su aparición, en aquel ya lejano campo donde campeaba y muy a sus anchas Pablo Neruda, donde todos, como ya sabemos, hasta la Mistral, caían bajo su pantagruélica y muchas veces indecorosa sombra. Ha tenido que pasar mucho tiempo, y barro, y lágrimas, y sudor mezclado con tinta para poner esa sombra en su lugar, su enorme lugar. Y la enormidad a veces, lamentablemente, es monstruosa: no se vaya a contagiar Parra -no sólo por mor de sus epígonos y el vampirismo académico e incluso editorial, sino por propia autocomplacencia-de enormidad. No puedo afirmar, tampoco lamentar, que Parra sea el poeta que más me ha conmovido en mi vida tanto como lector y como poeta, y sobre todo como hombre. Su primera lectura por allá por los primeros años 70 fue como un cortocircuito mental, como un golpe de corriente a mis convicciones y convenciones poéticas; pero se fue pasando. Yo leí a Parra antes que a Huidobro y a De Rokha, y al leer al pequeño Dios y al toro furioso, ya en la Universidad, por el año '76, sentí que tenían bastantes cuestiones que decirme en las que Parra ni se había asomado, preocupado de derrumbarlos de sus pedestales. Cosa que si vemos desde este tiempo en el que estamos, igual algo de

* Poeta. Profesor de español por la Universidad de Concepción. Cofundador de la revista Posdata. Académico de la Escuela de Literatura, Universidad Finis Terrae. Santiago, Chile. Correo: principe.prospero@gmail.com 
tarea sucia tenía, bueno, como toda pasión rupturista, que es lo que salva a toda la electrizante dinámica de la ruptura moderna, la pasión, cosa que acerca a todo poeta a un ideal romántico -Parra incluido-por más oculta -o disimulada- que esta pasión se encuentre bajo la ironía. Algo así como la pasión crítica de la que habla Octavio Paz. Al leer a César Vallejo supe sí que estaba ante un gran poeta, o mejor un profundo, un permanentemente insondable poeta. Y lo sigo leyendo así y así lo sigo creyendo. Entonces mi problema es que hoy, 25 de junio de 2014, el año en que Nicanor cumple 100, lo sigo más que afirmando, sintiendo, y la poesía es una cuestión que se siente, que te define, que te interpela y por la que te descubres a través de la Palabra. Lo demás viene después. El problema de Vallejo es que no se puede tocar, digo, desde una poética propia, sus poemas son oraciones para los que carecen de divinidad. Pero acá hablamos de Parra. El juicio intelectual, frío, académico o, incluso, como poeta, las preguntas (y sus respuestas) más cercanas a la objetividad, al distanciamiento: es difícil no redundar en la principal aportación de Parra no sólo en la poesía chilena sino también latinoamericana: la expulsión de la concepción romántica del poeta como vate, como un sujeto que se ofrece como una suerte de potencia casi sobrehumana que nos ilumina con mensajes que vienen siempre desde un más allá, otra parte, un locus ubicuo que en gran medida tiene poco que ver con la experiencia cotidiana del hombre. Por otra parte, también Parra está en otra situación que la de los surrealistas, que, como dice Octavio Paz de Breton y sus seguidores, situaron la inspiración en el inconsciente y dieron un paso más hacia otra modernidad, ya que finalmente la "inspiración" poética tenía un espacio definido, y este espacio se situaba en algún lugar del sujeto, del hombre: el inconsciente. Ahora, lo que Parra aporta, y es enorme dentro de las implicancias poéticas del siglo pasado y éste, es una voz que proviene de lo más inmediato y cotidiano, del hombre que deambula por la urbe, pero no en esa actitud de dandy del poeta baudeleriano, incluso de flâneur, aún situado en la modernidad del siglo XIX, sino el hombre con sus afanes aparentemente más nimios, más insignificantes, pero que, finalmente, son sus trabajos y sus días. Además, Parra hace, hasta el momento, irreversiblemente "posmoderna" la poesía en tanto que su habla surge de desplazamientos, desgarrones, quebraduras, intertextos populares y otros no tanto. Inolvidable su cita a Wittgenstein en medio de un antipoema, cuando Wittgenstein era cosa de pocos, poquísimos o casi nadie fuera de los herméticos círculos filosóficos, enmascaramientos, disolución del sujeto lírico, discursos de otros ámbitos textuales, recortados y reensamblados, como el caso del famoso "Quebrantahuesos", perpetrado con Enrique Lihn 
y Alejandro Jodorowsky. Ahora bien, toda esta deconstrucción del poeta moderno, del poeta vate, del poeta como portador de misterios insondables, como "ladrón de fuego", al decir de Rimbaud, no tendría el valor que tiene si no fuera por una recuperación para la poesía, de la palabra hablada, de la oralidad, con una modulación además de inteligentísima, muy sensible y original (etimológicamente considerado el término) y, también, y esto es fundamental para la poesía, muy transgresora y rupturista, como a la vez sensible y "bella" en el sentido estético de la idea, con todos, incluso sus momento más irreverentes y feroces, incluso hasta macabros y coprolálicos. Pero esto no quedaría completo si no se agrega que Parra recupera la oralidad para devolverla a la escritura, es decir, igualmente, la fluidez del signo oral es recobrado por la fijeza del signo escrito, irremediablemente. Pero lo más significativo es su actitud lírica desacralizadora, su "comportamiento" poético en permanente búsqueda del desarraigo, de estar fuera de las rayas de cancha. Bueno, es que es como debe comportarse un poeta ya sin Olimpo, su anti-pathos y también su fatalidad, como siguió comportándose después Lihn y Bertoni, Lira y Maquieira, incluso Zurita, que por otra parte ha declarado su admiración y deudas -las que todo poeta contrae para hacerse y Ser-con el anti-poeta. Sin duda la publicación de Poemas y antipoemas, en 1954 -donde surge la partícula distanciadora "anti", el más, para la época, que afortunado prefijo (los hay, y son la mayoría "desafortunados")- fue un libro inesperado en medio de la pleitesía nerudiana y de los asomos surrealizantes a destiempo de la Mandrágora. Otro hito memorable en su obra y en la poesía chilena fue Obra gruesa, publicada además en un fin de década memorable, 1969. También el gesto muy incomprendido en su tiempo, cuando editó esa especie de granada de mano, que habría podido explotarle en su propia cara -de alguna manera pasó así- que fueron los Artefactos, esas tarjetas con enunciados mínimos, como graffitis, que dispararon sin piedad a las ya malolientes instituciones siempre tan veneradas en este país: asunto que no le cayó bien ni a derechas ni a izquierdas, ni a ateos ni a cristianos. A mí me gusta mucho el giro que dio por los años de la dictadura cuando adoptó el enmascaramiento con el personaje de el Cristo de Elqui, en sus Prédicas y sermones..., pienso que ahí hay un punto de inflexión notable en su discurso, un giro, un agiornamiento, otro paso más a la originalidad de lo oral que, como dije más atrás, es irrevocablemente devuelto a lo escrito: Parra, creo, a pesar de ser un poeta que necesita adelantarse permanentemente, no podrá salir de un ámbito logocéntrico. Parra afirmaría sigue siendo un poeta logocentrista. Su Shakespeare es otra vuelta de tuerca más y sus discursos de sobremesa, como tales, están más 
cerca de aquel Parra "ingenioso" que poético -Parra es un poeta intenso cuando se lo propone-, pero de un ingenio de hidalgo, de ese ingenio de don Quijote. Ahora bien, espero con ansias su discurso poético sobre Cervantes, que imagino vendrá, así como los a Juan Rulfo y a Luis Oyarzún. Más ha reescrito y se ha referido a Shakespeare, pero creo que todos esos sujetos que Parra ha diseminado en su "anti-escritura" son más deudores de la locura manchega del Quijote. Ojalá nos regale un texto Parriano-Cervantino en este centenario de uno de los poetas más notables, irregular, inteligente, rupturista, desacralizador, lírico, que nos ha dado el siglo XX. Ahora, la única certeza desde esta mirada "testimonial" que podría asegurar sin lugar a equivocarme, es que sin Parra la poesía chilena no sería lo que es hoy, no habría evolucionado, en un comienzo, como lo hizo, e involucionado, posteriormente, como lo está haciendo, tal como la conocemos a estas alturas del siglo XXI. Parra es lo que para Dios a la humanidad, para la poesía chilena (no sé qué tanto más allá de nuestros lindes): si no hubiese existido, habría que haberlo inventado. 